\title{
Credit Risk, Islamic Contracts and Ownership Status: Evidence From Malaysian Islamic Banks
}

\author{
Faridah Najuna Misman ${ }^{1}$,Wahida Ahmad $^{2}$, Noor Sufiawati Khairani ${ }^{3}$ \& Nur Hazimah Amran ${ }^{4}$ \\ ${ }^{1}$ Department of Finance, Faculty of Business and Management, Universiti Teknologi MARA Johor Branch, Johor, \\ Malaysia \\ ${ }^{2}$ Arshad Ayub Graduate Business School, Universiti Teknologi MARA, Shah Alam, Selangor, Malaysia \\ ${ }^{3}$ Faculty of Accountancy, Universiti Teknologi MARA Johor Branch, Johor, Malaysia \\ ${ }^{4}$ Faculty of Business and Management, Universiti Teknologi MARA Puncak Alam, Selangor, Malaysia \\ Correspondence: Faridah Najuna Misman, Department of Finance, Faculty of Business and Management, Universiti \\ Teknologi MARA Johor Branch, Johor, Malaysia Tel: 60-7-935-2000. E-mail: farid978@uitm.edu.my
}

Received: May 12, 2020

doi:10.5430/ijfr.v11n3p106
Accepted: June 20, 2020

Online Published: June 29, 2020

URL: https://doi.org/10.5430/ijfr.v11n3p106

\begin{abstract}
The paper attempts to model the key drivers of credit risk for Islamic banks in Malaysia. This paper is motivated to introduce Islamic financing types (IFT) and banks ownership status (STATUS) as additional factors in investigating the key drivers. This study also investigates the level of credit risk between the crisis and non-crisis period. This study employs a panel data analysis method using generalized least squares (GLS) regression for random effect model. The dependent variable is credit risk which assumed to be a function of bank-specific variables and other potential variables that are ownership status, Islamic financing types and financial crisis. The sample of this study comprised of 160 observations for 15 full-fledged Islamic banks in Malaysia, covering the period of 2000 to 2016. The finding suggests that financing expansion, financing and capital buffer are amongst important drivers that significantly influence the level of credit risk of Malaysian Islamic banks. The estimation results of this study also suggest that any Islamic bank that offers equity-based financing (EBF) has significantly higher credit risk.
\end{abstract}

Keywords: credit risk, Islamic banks, Islamic financing types, financial crisis

JEL: C1, G01, G21, G29

\section{Introduction}

Islamic banking system functions parallel to the former type of banking system, conventional banking system. It is widely offered not only in Muslim dominant countries but also in countries with less Muslim population which include, United Kingdom, Germany and Switzerland. The existence of Islamic banks provides more options to customers in choosing the best platform for their savings, investment opportunities and financing services. Moreover, Islamic banking and finance industry in Malaysia are concerns on the technology driven business diversification. During 2016Q2 to 2017Q2, Malaysian Islamic banks and windows recorded an escalation of their average assets by $9.3 \%$. The escalation of average assets demonstrates the growing domestic market shares of Islamic banks and windows by $1.1 \%$ IFSB (2018). This indicates positive feedback and confidence from the customers in dealing banking businesses. For instance, global economies witnessed unfavorable economic health during the awaken of Global Financial Crisis (GFC) in 2008-2009. Yet, the adverse effects on the Islamic Financial Institutions are not substantial at least relative to the conventional (Alqahtani, Mayes, \& Brown, 2017). IFSB (2015) points out that Islamic Financial Institutions are less exposed to the crisis due to their natural practice of holding greater buffer of capital.

Islamic banks (IBs) are unique not only in terms of the principle of operations but also risk-related issues. For this reason, a few early studies argued that IBs carry more risks compared to conventional banks (CBs). This argument refers to the nature of operations and Shari ah prohibition being applied (Akkizidis \& Khandelwal, 2008; Cihák \& Hesse, 2008; M. Kabir Hassan \& Dicle, 2005; Sundararajan \& Errico, 2002). Ahmed and Khan (2007) claim that IBs are expected to face two types of risk: firstly, risk similar to the risk faced by CBs; and secondly, risks that are unique because they comply with Shari ah. The second category of risk that is related to Shari ah compels IBs to 
face more unique risks than CBs. According to Makiyan (2008), risk that is related to Shari ah can be further classified into two types: i) specific risk surrounding in IBs, e.g. risk related to PLS contracts; and ii) general risk surrounding IBs, e.g. legal, corporate governance and market structures. Among the risks face by Islamic banks, credit risk is the main risk that could affects their performance. An early study by Misman (2013) suggests that credit risk has the biggest stake in total risks of Islamic banks in Malaysia. Therefore, this current study examines in details the determinants of credit risk for Islamic banks specifically in Malaysia.

Earlier studies on credit risk determinants primarily focus on credit risk management among the conventional banks for example, Berger and DeYoung (1997), Cebenoyan and Strahan (2004) and Das and Ghosh (2007). Furthermore, the interest on Islamic banking system is undeniable as growing numbers of literature with regards to Islamic banks risk management were written favorably by researchers. Among others Louhichi and Boujelbene (2016) and Misman, Bhatti, Lou, Samsudin, and Rahman (2015).

Therefore, this paper attempts to investigate the key drivers of credit risk of Islamic banks in Malaysia. The purpose of this paper is to introduce Islamic financing types (IFT) and ownership status (STATUS) as additional factors in investigating the key drivers. This study focuses on Malaysian Islamic Financial Institutions due the reason of the exponential growth of the Islamic finance sector in the country since a few decades ago. Number of Islamic banking products and services has grown exponentially since the inception of the first Islamic bank in Malaysia which is Bank Islam Malaysia Berhad (BIMB) in 1983. In the earlier stage of their development in 1993, the growth of Islamic banking products and services is encouraged by the implementation of Interest-Free Banking Scheme (IFBS). The implementation of Interest-Free Banking Scheme allows conventional banks to offer Shariah approved products and services through Islamic windows. As at December 2018, there are sixteen (16) Islamic banks operating in Malaysia. It is worth noting that the development of Islamic banking and finance industry in Malaysia is strongly supported by the central bank, Bank Negara Malaysia (BNM). The top-down approach in building and strengthening the sector is one of the plausible approaches to bring up the Islamic Financial Sector in the country.

\section{Literature Review}

Credit risk management studies have attracted the attention of many parties, particularly in developed countries. Investigating the factors that drive the credit risk in the banking sector is not only important to the bank's management but also to regulatory authorities.

Prior studies measure the credit risk by using the ratio of non-performing loans (NPLs). In banking studies, the loan is classified as non-performing when the payment of interest and principal are overdue by 90 days or more. Hence, higher NPLs causes the banks to experience lower profit margins in which, jeopardizes the banking health. As a result, the threatened bank is likely to end up in a crisis. Potential influences on the NPLs include the types of borrower, bank management and adverse changes in the economic situation. The importance of efficient credit risk management invites relevant parties especially researchers, regulators and banks' management to investigate the determinants of credit risk in banking. Therefore, a breadth and in-depth investigation is crucial for a better understanding with regards to the issues of credit risk in banking followed by a comprehensive credit risk management framework. Notably, in the banking business, NPL is profoundly impinging on the banks' day-to-day operations and activities (Nikolaidou \& Vogiazas, 2017). Due to that reason, it is essential to keep NPLs at level in avoidance of further imperil.

Most studies suggest there are two strands of literature on the factors that drive credit risk. The most popular strand discloses credit risk is driven by several bank specific variables and the second strand argues that macroeconomic factors greatly influence the credit risk of banks. A survey of the literature discovers previous studies normally examine the determinants of credit risk either using bank specific variables or macroeconomic factors as explanatory variables. Previous studies include Louhichi and Boujelbene (2016) who examine the determinants of credit risk in Middle Eastern, North Africa and Asian countries using macroeconomic and bank specific variables as explanatory variables. The authors use two (2) complimentary approaches that are, one-step system generalized method of moments (SGMM) and panel vector autoregressive (PVAR). The authors employ NPLs ratio as proxy for the credit risk and discover both bank specific variables and macroeconomic variables significantly influence credit risk exposure in that countries for instance, greater provision, higher capitalization and the state of booming economy. Later studies that focus on the Sub-Saharan Africa empirics GDP growth rate reveal that it significantly influences the bank credit risk in negative direction (Mpofu \& Nikolaidou, 2018). The relationship portrays that credit risk exposure has higher tendency to increase in the case of unfavorable economy. This is due to the customers are unable to manage their credit during the downturn economy, therefore contribute to increasing number of defaulters. 
Nevertheless, there are solutions to these unfavourable economic scenarios. Among the bank specific variables that possibly stimulate the vulnerability of credit risk include growth of loan, quality of loan, management quality, bank size, loan concentrations and capital. The effect of bank specific variables on credit risk is still debatable because of the different practices and strategies of the bank in mitigating the risk. Berger and DeYoung (1997) disclose cost efficiency induces greater loans problem. Escalation of loans problem sparks off the credit risk vulnerability. To illustrate further, Berger and DeYoung (1997) hypothesize four (4) hypotheses with reference to the cost efficiency and loans problem that include (i) bad management, (ii) bad luck, (iii) moral hazard and (iv) skimping issue. The bad management hypothesis indicates low cost efficiency signals for imprudent management of banks. They further highlight that bad luck hypothesis is referring to external events induce greater loans problem. The authors explain the existing of moral hazard incentives taken by banks with low level of capital as the banks cannot easily being charged for the risk-taking activities. Presuming another party (i.e. parent bank) is bearing the risk partially, small banks tend to take higher risk that cause to greater loans problem. Meanwhile, the last hypothesis notes that amount of resources allocation to monitor the loans affect both quality of loans and cost efficiency. Unlike bad management, moral hazard hypothesis stresses on large bank faces higher problem of loans. This is due to the large bank holds greater level of capital in which, encourages the involvement in risky type of investments and projects. Angbazo (1997) finds significant relationship between bank size, net interest margin and credit risk. In the study, the author posits that different size of banks have different credit risk exposure. Similarly, Gulati, Goswami, and Kumar (2019) empirically show that size of banks in India influence the credit risk. The authors indicate larger size of banks in the industry are exposed to greater credit risk. On top of offerings large volume of financing, these banks also provide financing to various types of business, hence the banks are largely exposed to each business individual risks. In another study, Louhichi and Boujelbene (2016) highlight capital, asset quality, management quality and profitability affect credit risk of banks in Organization of Islamic Cooperation (OIC) countries. The study indicates that credit risk exposure reduces for the banks with low capitalization, greater asset quality, prudent management quality and greater profitability. Perić, Smiljanić, and Aljinović (2018) distinguish different effect of credit risk in Central and Eastern European (CEE) countries in reference to bank ownership. This is due to different regulatory environmental practices between the countries. Adding to the noise, Boateng, Liu, and Brahma (2018) discover both macroeconomic variables and bank specific variables play important role in determining credit risk of Chinese commercial banks. The authors point out GDP and unemployment is positive and statistically significant to the banks credit risk meanwhile, inflation, size of the banks and types of banks ownership are significant but inversely related.

\section{Islamic Banks and Credit Risk}

Over decades, research and interest in risk management in Islamic banks has grown tremendously. An increasing number of studies on risk management of Islamic banks focus on the processes of risk management, Sharia issues and related risks faced by the banks. However, issues with reference to credit risk management are widely debatable due to the heterogeneous characteristics of the banks in which, differently practicing the mitigation approaches in managing the vulnerable of credit risk.

Among the growing literature on the risk determinants particularly, credit risk include Kabir, Worthington, and Gupta (2015), Lassoued (2018) and Misman et al. (2015). Several empirical analyses examine on the risk and most of the analyses use a single country and bank specific variables as the explanatory variables. According to Alandejani and Asutay (2017) Islamic banks in Gulf Cooperation Council (GCC) countries face lower credit risk as a result of greater sectoral Islamic financing growth especially, real estate and construction sector relative to conventional counterparts. Evidently, the study reveals that credit risk level is higher in fixed-income debt financing rather than profit and loss sharing financing. This indicates escalation of fixed-income debt financing is able to jeopardize the quality of loan exceeding the profit and loss sharing (PLS) instruments. The researchers additionally note efficiency of banks affect the credit risk vulnerability.

Indeed, lack of monitoring activities towards the borrowers raise the volume of non-performing financing hence, boost the banks credit risk. M. Kabir Hassan, Khan, and Paltrinieri (2018) claim that Islamic banks perform better than conventional counterparts in combating the credit risk in banking system. The better credit risk management in Islamic banks is due to various reasons. Among primary reasoning are ensuring the underlying assets that involve in transactions which are related to the real economic activity and the diverse types of products offered relative to conventional counterparts. Another reason is the fundamental difference between Islamic banks and conventional counterparts with regards to penalties in the case of late payment. Abdul-Rahman, Sulaiman, and Said (2017) share similar point of views which indicate inability of the borrowers to repay the financing cause to vulnerable of credit risk. In contrast, Lassoued (2018) argues that Malaysian Islamic banks face greater credit risk exposure as compared to conventional counterparts. The author further explains the greater credit risk exposure stems from the market segmentation, restrictions on the investment opportunities and practice of profit and loss sharing. 
Literally credit expansion encourages economic growth of a country. In other streamline, improper management of credit expansion deteriorates the asset quality thus, contributes to greater credit risk (Ibrahim \& Rizvi, 2018). It is emphasized that Islamic banks does not only extend the financing supply to the economies, but these banks show higher financing growth relative to conventional counterparts. However, the authors are unable to provide significant evidence of Islamic banks face greater risk exposure by expanding the financing during the crisis period. Trad, Trabelsi, and Goux (2017) discover size and bank capitalization are the main drivers of credit risk management. The authors further highlight that large size and greater capitalization of Islamic banks lead to prudent credit risk management. Large size of Islamic banks apparently involves in different activities, in which facilitate to better diversification and risk absorption. In the sense of capitalization, increase in capital promotes the Islamic banks stability in addition to good risk reduction capability.

\section{Data Description and Methodology}

This section explains the details of the data description and the methodology of the study. The discussion includes the introduction of proxies and definition of each variables in the model. Section 3 concludes with the model development for the study, presented in equation form.

\subsection{Data}

The data for this study is based on the financial statement of Malaysian Islamic banks obtained from the Bankscope database and individual bank's website. The sample of this study comprised of 15 full-fledged Islamic banks in Malaysia, covering the period of 2000 until 2016. A total of 160 observations of unbalanced panel were carried out. The panel is unbalanced because some of the sample banks are established in later years relative to other banks, for example in 2005, 2006 and 2007. Table 1 presents a summary of selected variables used in this study.

Table 1. Variables proxies and definitions

\begin{tabular}{|c|c|c|}
\hline & Notation & Proxy Measurement \\
\hline \multicolumn{3}{|l|}{ Dependent Variable } \\
\hline Credit risk & $\mathrm{CR}$ & Non-performing financing to total financing $(\%)$ \\
\hline \multicolumn{3}{|l|}{ Independent Variables } \\
\hline Financing expansion & FEXP & Total financing to total assets (\%) \\
\hline Financing quality & FLP & Loan loss provision to total assets (\%) \\
\hline Capital buffer & $\mathrm{CB}$ & Total equity to total assets (\%) \\
\hline Capital requirement & CAPR & Total TIER 1 and TIER 2 to total assets (\%) \\
\hline Earnings & NIM & Net interest income to average earnings assets (\%) \\
\hline Management efficiency & MGT & Total earning assets to total assets (\%) \\
\hline Size & SIZE & Total assets (billion USD) \\
\hline Equity-based financing & EBF & 1 for equity-based financing, 0 otherwise \\
\hline Status & STATUS & 1 for foreign incorporated Islamic banks, 0 otherwise \\
\hline Financial Crisis & CRISIS & 1 for crisis period, 0 otherwise \\
\hline
\end{tabular}

\subsection{Methodology}

In an effort to investigate the key determinants of credit risk of Malaysian Islamic banks, the study employs a panel data analysis method. This study follows the approaches used by Lassoued (2018) to estimate the driver of credit risk of Malaysian Islamic banks. As displays in equation (1), the dependent variable non-performance financing is modeled to be a function of the selected bank-specific variables.

$$
C R_{i t}=f\left(x_{i t}, u_{i t}\right)
$$

$C R$ is the observed credit risk for Islamic bank $i$ at time $t$. Credit risk is defined as a ratio of non-performing financing to total financing. $x_{i t}$ is a vector of bank-specific characteristic which have an impact on the credit risk and the error term $u_{i t}$ is representing all the other unobserved macroeconomics and regulatory factors that affect credit risk. The bank-specific variables include financing expansion (FEXP), financing quality (FLP), capital buffer (CB), capital requirement (CAPR), earnings (NIM), management efficiency (MGT) and size of the banks (SIZE). This study also investigates the effect of financing types on the credit risk in which, uses Islamic financing structures in order to do so. This current study uses a dummy to represent the banks that offer a profit and loss sharing contract known as equity-based financing (EBF). The effect of Global Financial Crisis (GFC) 2008-2009 is also been tested in this study. In examining the effect of the GFC, a crisis dummy is added to the model (CRISIS). This study also 
controls the ownership status in the estimation model. The objective is to examine whether there is any difference between local and foreign ownership in regard to credit risk level. Past studies concentrate on this issue from a different perspective. Most of the studies focus on the proportion of the ownership share. For example Boateng et al. (2018) use ownership type which proxy by proportion of equity in bank hold by the state or its agencies and private investors as a ownership variables. For the analysis purposes, an ownership status is proxy by STATUS dummy. STATUS is equal to ' 1 ' for foreign ownership banks and ' 0 ' for local ownership banks. The equation model is presented in equation (2).

$$
\begin{aligned}
C R_{i t}= & \beta_{0}+\beta_{1} F E X P_{i t}+\beta_{2} F L P_{i t}+\beta_{3} C B_{i t}+\beta_{4} C A P R_{i t}+\beta_{5} N I M_{i t}+\beta_{6} M G T_{i t}+\beta_{7} S_{I Z E_{i t}}+\beta_{8} E B F_{i t}+ \\
& \beta_{9} \text { STATUS }_{i t}+\beta_{10} \text { CRISIS }_{i t}+\varepsilon_{i t}
\end{aligned}
$$

\section{Empirical Findings and Discussion}

The study constructs credit risk model with the aims to examine the potential drivers of the risk by considering the bank specific variables for Malaysian Islamic banks. There are ten (10) explanatory variables including three (3) dummies representing banks that offer equity-based financing in their operation and dummy status to distinguish between local and foreign Islamic banks. In addition, the model includes crisis dummy to control the effect of the Global Financial Crisis (GFC) 2008-2009. The focal interests of the model are to investigate the possible effects of financing expansion, financing quality, capital buffer, capital requirement, earnings, management efficiency, bank size, the offering of EBF and ownership status on credit risk of Islamic banks in Malaysia. The study conducts variance inflation factor (VIF) test to identify and eliminate possible multicollinearity issue. The mean VIF for the model is 1.79 which implies there is no serious multicollinearity issue in the model.

The paper presents generalized least squares (GLS) random effect model to empirically respond to the study hypotheses. Table 2 exhibits the random effect estimation for the credit risk model. The descriptive statistics and proportion of dummy variables are described in Appendix A and Appendix B respectively.

Table 2. Random effect model estimation

\begin{tabular}{lcr}
\hline & Coefficient & z-value \\
\hline Financing expansion & $-0.159^{* * * *}$ & -5.680 \\
Financing quality & $1.804^{* * *}$ & 7.670 \\
Capital buffer & $0.391^{* * *}$ & 2.870 \\
Capital requirement & -0.077 & -0.750 \\
Earnings & -0.027 & -0.100 \\
Management efficiency & -0.010 & -0.520 \\
Size & $-0.024^{*}$ & -1.720 \\
Equity based financing & $2.146^{* * *}$ & 3.090 \\
Status & $-2.123^{* * *}$ & -2.630 \\
Crisis & -0.325 & -0.410 \\
cons & $10.357^{* * *}$ & 4.060 \\
\hline Wald chi2 (11) & $169.82^{* * * *}$ & \\
R-squared (between) & 0.7654 & \\
Observations & 160 & \\
\hline
\end{tabular}

Notes: i) The table presents estimation results using generalized least squares (GLS) random effect model. The dependent variable is the Credit risk, proxy by ratio of non-performance financing to total financing. The independent variables are Financing expansion is the ratio of total financing to total assets; Financing quality, the ratio of loan loss provision to total assets; Capital buffer, the ratio of total equity to total assets; Capital requirement, the ratio of TIER 1 and TIER 2 to total assets; Earnings, net interest margin; Management efficiency, the ratio of total earning assets to total assets; Size, the total assets (billion USD); EBF is 1 for equity based financing, 0 otherwise; STATUS is 1 for foreign Islamic banks, 0 otherwise. Crisis is 1 for 2008 and 2009, 0 otherwise. ii) ***, ** and * denotes significance at $1 \%, 5 \%$ and $10 \%$ levels, respectively. The estimations are conducted on unbalanced panel data of 160 observations from 2000-2016.

The model of 15 Islamic banks ends up to 160 observations of unbalanced panel. The model estimation is fit with significant Wald chi2 statistic and 76.54 percent $\mathrm{R}$-squared. The regression discovers six (6) important determinants 
of credit risk for Malaysian Islamic banks that are financing expansion, financing quality, capital buffer, bank size, equity-based financing and status. Meanwhile capital requirement, earnings and management efficiency are not statistically significant in determining credit risk for these Islamic banks.

The estimation reveals meaningful findings where financing expansion and financing quality become the essential determinants of credit risk for Islamic banks. The inverse relationship between financing expansion and credit risk disclose Islamic banks that are aggressive with financing activities are exposed to lesser credit risk. This result is similar to Rahman and Shahimi (2010) who also found an inverse effect between an increase in amount of financing and credit risk. This implies Islamic banks in Malaysia are prudent in their financing activities and the financing offered are graded as superior quality of assets. The finding is further supported by the negative association between financing quality and Islamic bank credit risk. Note that financing quality is reported using inverse proxy of loan loss provision. The relationship indicates Islamic banks with higher financing quality experience lower credit risk. This finding is supported by Louhichi and Boujelbene (2016). They claim that greater quality will contribute to lower credit risk level. Therefore, the banks should have a tighten policy in giving financing to ensure that they have better quality of financing.

The study also included two (2) proxies related to banks capital that are capital buffer and capital requirement. Capital buffer measures the capability of banks to cushion for sudden losses using their equity capital. Capital requirement measures the regulatory capital adequacy that must be fulfilled by banks. This study shows a consistent result with Alandejani and Asutay (2017). It is evident that Islamic banks that hold substantial capital buffer are exposed to greater credit risk. The finding divulges Islamic banks that have higher capital to buffer for sudden losses have greater tendency to engage in risky investment. This may lead to aggressive financing disbursement and thus the banks are exposed to higher credit risk. On contrary, there are opposite relationship between capital requirement and credit risk, connote the higher the capital adequacy requirement Islamic banks are exposed to lesser credit risk. The relationship is however do not have statistical evidence. The insignificant relationship is justifiable due to the mandatory capital adequacy requirement set up by the regulator. Furthermore, the capital ratio comprises of profit-sharing investment account hence it lessens the credit risk exposure. The profit-sharing investment account is capable to reduce the credit risk exposure due to its risk absorbent characteristics.

It is common for an Islamic bank to offer trading-based financing. On top of that, many banks recently offer more options on types of financing such as equity-based financing (EBF) and other supporting-based financing (SBF). While most Islamic banks in the country offer trading-based financing, the study consists of 60 percent of overall observations in this model that offers EBF. Equity based financing refers to profit and loss sharing contract and this type of financing is expected to surge credit risk exposure to the bank. The estimation result supports the argument where Islamic banks that offer EBF have significantly higher credit risk then banks who do not offer EBF. In the sense of EBF, banks have higher tendency to be involved in high risky investment due to at least three (3) possible reasons. Firstly, banks are more aggressive in investment because of comfort position of equity capital. Secondly, holding excessive amount of capital without strategic investment causes idle capital and loses to the bank. The third possible reason is the bank opt to locks for risky investment mainly for the promising expected returns. However, the result is contradicted with Alandejani and Asutay (2017). Alandejani and Asutay claim that, debt-based financing expose banks to higher credit risk as compare to the profit loss sharing financing. This situation might happen due to the decision of the bank taking excessive amount certain type of financing or unbalance proportion between debt based and equity-based financing

The study probes the relationship between banks income generation and credit risk via earnings and management efficiency. Islamic banks that obtain higher earnings and management efficiency experience lesser credit risk due to their capability in income generation and management. However, the study is unable to find statistical evidence on the relationship between earnings and credit risk for Islamic banks in Malaysia. Management efficiency is also projected not to have any significant impact on Islamic banks credit risk.

The size of Islamic banks in the country plays vital role in influencing credit risk. The study unveils larger Islamic banks are exposed to lower credit risk. The finding indicates diligent mitigation of credit risk among large Islamic banks in Malaysia. Meanwhile smaller Islamic banks in the country may have some restriction and limitation to mitigate credit risk and thus are exposed to greater risk. The results support the moral hazard hypothesis discusses in Berger and DeYoung (1997) that justify excessive risk-taking activities by small banks.

The ownership status also is one of the focus in this study. Ownership status of banks is classified as either a local or foreign owned bank. Status dummy takes a value of one for foreign owned banks and zero for local owned banks. Unsurprisingly, the model uncovers foreign Islamic banks in Malaysia face lesser credit risk than domestic Islamic 
banks. The credit risk for foreign banks is statistically lower than domestic banks is explainable founded on larger capital based of foreign Islamic banks that are highly likely injected from their parent bank. Other than that, foreign banks may bring their expertise and synergise with the local expertise to strengthen their risk governance. Lensink and Hermes (2004) also claim that international expertise will transfer the knowledge and skills to the local personnel and indirectly improve bank's risk management governance.

This study also investigates the impact of GFC on the credit risk of Malaysian Islamic banks. Malaysian was hit by the GFC in mid-2008. In order to examine whether the crisis has some impacts on the credit risk level, the crisis dummy is included in the estimation model. The inclusion of crisis in the model fails to proof any significant different of credit risk during the crisis and non-crisis period. Therefore, the study concludes that Islamic banks in Malaysia manage their credit risk in similar manner regardless of the two periods.

\section{Summary and Conclusion}

The aim of this study is to examine the key drivers of credit risk in Malaysian Islamic banks for the period of 17 years from year 2000 to 2016. The results highlight new and useful findings to the Islamic banking literature. The finding identifies relevant important drivers that influence the level of credit risk of Malaysian Islamic banks. The finding suggests that financing quality, capital buffer and financing expansion have significant influence on the credit risk of Malaysian Islamic banks. The higher proportion of low-quality financing gives negative impact to the level of credit risk. According to the findings, it gives a signal that the management of Islamic banks in Malaysia should give extra attention to the financing quality. The banks should come out with more stringent policy in giving financing to ensure that the proportion of low-quality financing is small and manageable. While for the capital buffer, the positive sign explains that banks with higher equity level tend to engage to more risky financing activities. This is suggesting that, higher equity banks believe that they will have enough capital to buffer any losses that might incur by the banks. The result also suggests for Islamic banks in Malaysia to execute prudent financing expansion as it may lower the bank exposure to credit risk.

This study also examines the effect of Islamic financing contract on the credit risk. There are three (3) categories of contract in the operation of Islamic banks. The study highlights equity-based financing (EBF) is a profit and loss sharing contract that carry higher credit risk compared to the trading-based and supporting-based financing. The estimation results of this study supports the relationship where Islamic banks that offer EBF have significantly higher credit risk. Thus, Islamic banks manager may put extra weight in analysing the credit worthiness of their customers. This is because the nature of equity-based financing is similar to the partnership or joint venture, whereas the Islamic banks will also share the losses face by the partner (borrower). The banks should also monitor and be involved directly in the venture so that they can reduce the chances of default risk. The banks that offer equity-based financing contract of financing should have efficient risk management framework and specific policy that will help them in mitigating the credit risk arise from EBF contract.

Ownership status is also one of the important aspects in this study. The sample of 15 Islamic banks in this study are represent by 5 foreign owned Islamic banks. The result reveals that foreign Islamic banks faced a lower credit risk compared to the local ones. This implies that foreign Islamic banks may have prudent risk management framework and expertise as they may apply the practices by their parents' banks. The synergy between foreign and local expertise helps the banks to perform better. Hence, in order to enhance the performance of Malaysian local Islamic banks in credit risk management the study proposes, the managers, the policy makers and the regulators in exemplary the risk governance model of foreign Islamic banks.

The study concentrates only on Malaysian full-fledged Islamic banks therefore the sample may be limited. Forthcoming studies may include more countries and perhaps make a comparison between those countries. Regardless of the limitation, this study provides empirical evidences to the existing literature specifically in the Islamic banks risk management areas.

\section{Acknowledgments}

The authors would like to thank the Ministry of Higher Education Malaysia and Universiti Teknologi MARA for the financial support through Fundamental Research Grant Scheme (FRGS)-600-RMI 5/3 (031/2016).

\section{References}

Abdul-Rahman, A., Sulaiman, A. A., \& Said, N. L. H. M. (2017). Does financing structure affects bank liquidity risk?. Pacific-Basin Finance Journal. https://doi.org/10.1016/j.pacfin.2017.04.004 
Ahmed, H., \& Khan, T. (2007). Risk Management in Islamic Banking. In M. K. Hassan, \& M. K. Lewis (Eds.), Handbook of Islamic Banking (pp. 144-158). Cheltenham,UK: Edward Elgar Publishing Limited.

Akkizidis, I., \& Khandelwal, S. K. (2008). Financial Risk Management for Islamic Banking and Finance. New York: Palgrave Macmillan.

Alandejani, M., \& Asutay, M. (2017). Nonperforming loans in the GCC banking sectors: Does the Islamic finance matter?. Research in International Business and Finance, 42, 832-854. https://doi.org/10.1016/j.ribaf.2017.07.020

Alqahtani, F., Mayes, D. G., \& Brown, K. (2017). Reprint of Economic turmoil and Islamic banking: Evidence from the Gulf Cooperation Council. Pacific-Basin Finance Journal, 42, 113-125. https://doi.org/10.1016/j.pacfin.2016.06.013

Angbazo, L. (1997). Commercial bank net interest margins, default risk, interest-rate risk, and off-balance sheet banking. Journal of Banking \& Finance, 21(1), 55-87. https://doi.org/10.1016/S0378-4266(96)00025-8

Berger, A. N., \& DeYoung, R. (1997). Problem loans and cost efficiency in commercial banks. Journal of Banking \& Finance, 21(6), 849-870. https://doi.org/10.1016/S0378-4266(97)00003-4

Boateng, A., Liu, Y., \& Brahma, S. (2018). Politically connected boards, ownership structure and credit risk: Evidence from Chinese commercial banks. Research in International Business and Finance. https://doi.org/10.1016/j.ribaf.2018.07.008

Cebenoyan, A. S., \& Strahan, P. E. (2004). Risk management, capital structure and lending at banks. Journal of Banking \& Finance, 28(1), 19-43. https://doi.org/10.1016/S0378-4266(02)00391-6

Cihák, M., \& Hesse, H. (2008). Islamic Banks and Financial Stability: An Empirical Analysis. IMF Working Paper. Available at SSRN eLibrary, 08/16, 1-29.

Das, A., \& Ghosh, S. (2007). Determinants of Credit Risk in Indian State-Owned Banks: An Empirical Investigation. Economic Issues, 12(2), 27-46. Retrieved from http://www.economicissues.org.uk/

Gulati, R., Goswami, A., \& Kumar, S. (2019). What drives credit risk in the Indian banking industry? An empirical investigation. Economic Systems, 43(1), 42-62. https://doi.org/10.1016/j.ecosys.2018.08.004

Hassan, M. K., \& Dicle, M. F. (2005). Basel II and Regulatory Framework for Islamic Banks. Journal of Islamic Economics, Banking and Finance, 1(1).

Hassan, M. K., Khan, A., \& Paltrinieri, A. (2018). Liquidity Risk, Credit Risk and Stability in Islamic and Conventional Banks. Research in International Business and Finance. https://doi.org/10.1016/j.ribaf.2018.10.006

Ibrahim, M. H., \& Rizvi, S. A. R. (2018). Bank lending, deposits and risk-taking in times of crisis: A panel analysis of Islamic and conventional banks. Emerging Markets Review, 35, 31-47. https://doi.org/10.1016/j.ememar.2017.12.003

IFSB. (2015). Compilation Guide on Prudential and Structural Islamic Financial Indicators: Supplement. In Islamic Financial Services Board.

IFSB. (2018). Islamic Financial Services Industry Stability Report 2018. Retrieved from Kuala Lumpur, Malaysia.

Kabir, M. N., Worthington, A., \& Gupta, R. (2015). Comparative credit risk in Islamic and conventional bank. Pacific-Basin Finance Journal.https://doi.org/10.1016/j.pacfin.2015.06.001

Lassoued, M. (2018). Comparative study on credit risk in Islamic banking institutions: The case of Malaysia. The Quarterly Review of Economics and Finance. https://doi.org/10.1016/j.qref.2018.05.009

Lensink, R., \& Hermes, N. (2004). The short-term effects of foreign bank entry on domestic bank behaviour: Does economic development matter?. Journal of Banking \& Finance, 28(3), 553-568. https://doi.org/10.1016/S0378-4266(02)00393-X

Louhichi, A., \& Boujelbene, Y. (2016). Credit risk, managerial behaviour and macroeconomic equilibrium within dual banking systems: Interest-free vs. interest-based banking industries. Research in International Business and Finance, 38, 104-121. https://doi.org/10.1016/j.ribaf.2016.03.014

Makiyan, S. N. (2008). Risk Management and Challenges in Islamic Banks. Journal of Islamic Economics, Banking and Finance, 4(3), 45-54. 
Misman, F. N. (2013). Credit risk management of Islamic banks: a cross-country study. (PhD), La Trobe University, Australia.

Misman, F. N., Bhatti, I., Lou, W., Samsudin, S., \& Rahman, N. H. A. (2015). Islamic Banks Credit Risk: A Panel study. International Accounting and Business Conference 2015, Iabc 2015, 31, 75-82. https://doi.org/10.1016/S2212-5671(15)01133-8

Mpofu, T. R., \& Nikolaidou, E. (2018). Determinants of credit risk in the banking system in Sub-Saharan Africa. Review of Development Finance. https://doi.org/10.1016/j.rdf.2018.08.001

Nikolaidou, E., \& Vogiazas, S. (2017). Credit risk determinants in Sub-Saharan banking systems: Evidence from five countries and lessons learnt from Central East and South East European countries. Review of Development Finance, 7(1), 52-63. https://doi.org/10.1016/j.rdf.2017.01.003

Perić, B. Š., Smiljanić, A. R., \& Aljinović, Z. (2018). Credit risk of subsidiaries of foreign banks in CEE countries: Impacts of the parent bank and home country economic environment. The North American Journal of Economics and Finance, 46, 49-69. https://doi.org/10.1016/j.najef.2018.03.009

Rahman, A. A., \& Shahimi, S. (2010). Credit Risk and Financing Structure of Malaysian Islamic Banks. Journal of Economic Cooperation and Development, 31(3), 83-105.

Sundararajan, V., \& Errico, L. (2002). Islamic Financial Institutions and Products in The Global Financial System: Key Issues in Risk Management and Challenges Ahead. IMF Working Paper, 02(192).

Trad, N., Trabelsi, M. A., \& Goux, J. F. (2017). Risk and profitability of Islamic banks: A religious deception or an alternative solution? European Research on Management and Business Economics, 23(1), 40-45. https://doi.org/10.1016/j.iedeen.2016.09.001

Appendix A. Descriptive statistics

\begin{tabular}{lrrrrrrrr}
\hline Variable & $\mathrm{N}$ & mean & $\mathrm{min}$ & $\mathrm{p} 50$ & $\max$ & $\mathrm{sd}$ & skewness & kurtosis \\
\hline Credit risk & 163 & 4.20 & 0.07 & 1.82 & 28.74 & 5.22 & 2.07 & 7.17 \\
Financing expansion & 174 & 57.86 & 0.83 & 61.83 & 83.25 & 14.62 & -1.11 & 4.36 \\
Financing quality & 173 & 1.19 & -0.26 & 0.99 & 10.00 & 1.25 & 4.64 & 31.48 \\
Capital buffer & 174 & 8.94 & -1.70 & 7.51 & 77.18 & 6.90 & 6.34 & 58.34 \\
Capital requirement & 174 & 17.42 & -2.47 & 14.62 & 191.79 & 15.19 & 9.22 & 102.33 \\
Earnings & 167 & 2.76 & 0.11 & 2.49 & 7.42 & 1.29 & 0.89 & 3.87 \\
Management efficiency & 174 & 87.82 & 22.19 & 91.74 & 150.32 & 18.19 & 0.26 & 5.64 \\
Size & 174 & 16.44 & 0.10 & 7.27 & 181.79 & 25.94 & 3.69 & 19.71 \\
\hline
\end{tabular}

Appendix B. Proportion of dummy variables

\begin{tabular}{lc}
\hline Dummy Variables & Proportion \\
\hline Types of financing: & \\
Equity-based financing & 0.40 \\
Otherwise & 0.60 \\
\hline Status: & \\
Foreign Incorporated IBs & 0.28 \\
Domestic Incorporated IBs & 0.72 \\
\hline Crisis: & \\
Crisis Period & 0.17 \\
Non crisis period & 0.83 \\
\hline
\end{tabular}

